\title{
Plasma Concentration of Galanin in Chronic Hemodialysis Patients
}

\author{
Ioannis Legakis ${ }^{*}, 1$,Vasilliki Dardioti ${ }^{2}$ and Spyros Moutafis ${ }^{2}$ \\ ${ }^{I}$ Department of Endocrinology and Metabolism, ${ }^{2}$ Department of Nephrology, Henry Dunant Hospital, Athens, Greece
}

\begin{abstract}
Galanin has diverse physiological functions, including nociception, arousal/sleep regulation, congnition, and many aspects of neuroendocrine activities that are associated with feeding, energy metabolism, thermoregulation, osmotic and water balance, and reproduction.

In an attempt to clarify the metabolic profile of circulating galanin in blood, we examined plasma galanin concentration in patients with end-stage renal disease undergone hemodialysis. Our data document that galanin levels were reduced compare to post-dialysis levels and highlight an altered metabolic profile of galanin in renal failure.
\end{abstract}

Keywords: Plasma concentration, galanin, chronic hemodialysis, patients.

\section{INTRODUCTION}

Galanin, a 29-amino acid peptide originally isolated from porcine intestine is widely distributed in the central and peripheral nervous systems and the endocrine system [1]. It is involved both in hormones secretion from the hypothalamus and pituitary[2] and, perhaps, in important processes such in pain, memory, reproduction, and food intake [3-5].

Yet, very little is known concerning the metabolism of circulating galanin levels in blood. As an attempt to address this issue,we examined plasma galanin concentration in patients with end-stage renal disease undergone hemodialysis. The patients included 9 males aged 48 to 65 years $(59 \pm 5.9 \mathrm{yr})$ and 6 females aged 49 to 62 years $(55.8 \pm 5.03 \mathrm{yr})$, being on dialysis procedure for $120 \pm 24$ months. Each patient gave informed consent to the study. No patient had fever, leucocytosis or other signs of inflammation or infection for 1 month before entering the study.

Hemodialysis treatment was performed using biocompatible membranes (Polyflux 6L or Polyflux 8L). Blood samples were obtained immediately before the hemodyalytic treatment and heparin administration (To) and 4 hours after the start of dialysis $\left(\mathrm{T}_{(4)}\right)$ in the mid week session, 48 hours after the previous treatment. Both samples were taken in EDTA vials from the arterial site of the vascular access and immediately centrifigured. Human plasma galanin was determined by a radioimmunoassay, with a sensitivity limit of $1,0 \mathrm{pg} / \mathrm{ml}$ (Peninsula laboratories, Belmont, CA), as previously described [5]. The statistical analysis was performed by SPSS 8.0 (G 2000,SPSS Inc,

*Address correspondence to this author at the "Henry Dunant" Hospital, 33 Alimousion Street, Thision, 11851, Athens, Greece; Tel: \#30 1 6526655; Tel: \#30 1 7772253; E-mail: ilegak@med.uoa.gr
Chicago, Illinois 60606). $\quad \mathrm{p}<0,005$ was considered statistically significant.

According to the results, galanin concentration was significantly increased after $4 \mathrm{hr}$ of hemodialysis $\left(\mathrm{T}_{(4)}\right)$ in comparison to those at the start of the session (To) $\left[\left(\mathrm{T}_{(4)}\right)\right.$ : $15.4 \pm 0.4 \mathrm{pg} / \mathrm{ml}$ (To): $11.2 \pm 0.7 \mathrm{pg} / \mathrm{ml}, \mathrm{p}<0.001]$.

The present study clearly confirmed that before the initiation of dialysis therapy, galanin levels were reduced compare to post treatment levels. All patients were receiving epoetin so that $\mathrm{Ht}$ increased up to $30 \%$.We carried out a multiple logistic regression analysis in various biochemical parameters although the value of this statistical investigation may be limited because of a large number of contributing factors. Nevertheless, the obtained data indicated that BUN, $\mathrm{HCO} 3$ and $\mathrm{Ht}$ were independent factors for a change in galanin levels. Further assessment of human galanin will benefit from the identification of agents that can modulate systemic galanin levels. For instance the differential effects exerted by the increased peptides levels, known to occur in chronic renal failure, on galanin metabolism might elucidate our findings.

These results underline an altered metabolic profile of galanin in renal failure and signify the need of further studies in order to clarify this issue.

\section{ACKNOWLEDGEMENT}

Declared none.

\section{CONFLICT OF INTEREST}

Declared none.

\section{REFERENCES}

[1] Vrontakis ME. Galanin: a biologically active peptide. Curr Drug Targets CNS Neurol Disord 2002; 1: 531-41.

[2] Giustina A, Licini M, Schettino M, Doga M, Pizzocolo G, NegroVilar A. Physiological role of galanin in the regulation of anterior pituitary function in humans. Am J Physiol 1994; 266(1 Pt 1): E5761 . 
[3] Wilding JP. Neuropeptides and appetite control. Diabet Med 2002; 19: 619-27.

[4] Legakis IN. The role of galanin in metabolic disorders leading to type 2 diabetes mellitus. Drug News Perspect 2005; 18: 173-7.
[5] Legakis IN, Mantzouridis T, Mountokalakis T. Positive correlation of galanin with glucose in healthy volunteers during an oral glucose tolerance test. Horm Metab Res 2007; 39: 53-5.

Received: July 17, 2011

Revised: August 31, 2011

Accepted: December 9, 2011

(C) Legakis et al.; Licensee Bentham Open.

This is an open access article licensed under the terms of the Creative Commons Attribution Non-Commercial License (http://creativecommons.org/licenses/by$\mathrm{nc} / 3.0 /$ ) which permits unrestricted, non-commercial use, distribution and reproduction in any medium, provided the work is properly cited. 